\title{
Football Passing and Control Skills Exercise Model Based on Small Side Games For Ages 12-14 Years
}

\author{
Akhmad Anwar ${ }^{1}$, Widiastuti², Yasep Setiakarnawijaya ${ }^{3}$ \\ ${ }^{1-3}$ Sports Education in State University of Jakarta, Indonesia \\ tu.pps@unj.ac.id
}

\begin{abstract}
This study aims to produce soccer passing and control skills training models based on small side games for ages 12-14 years and to test the effectiveness of the models produced. The research method used in this study is the research and development method of Borg and Gall by using 10 stages and with the research subjects are football athletes aged 12-14 years in the East Jakarta football school. This research begins with needs analysis, planning, making trial products, revisions and final products. Test the effectiveness of the model using the loughborough soccer test (LSPT) which is used to determine the level of passing and control abilities of the athlete before and after the treatment model developed. The results of the study show that the product model of this exercise is feasible to use, in the results of small group trials and large groups can explain that the model as a whole can be done well. In the results of the effectiveness test, test the significance of differences with SPSS 16 Independent Samples Test obtained results in the experimental group with an average of 47.61 and the control group with an average of 49.80, these results derived from the test scores in the form of the final time velocity, so the time is smaller the better it gets. Fill in the results of the experimental group and the control group or mean difference $=2.188$, $t$-count $=3.845, d f=58$, with $\neg$-value $=$ $0.000<0.05$, it can be concluded that there are significant differences between the experimental group and the control group. These results indicate that the treatment given to the experimental group, namely the passing and control soccer skills training model based on small side games for 12-14 year olds has higher effectiveness and can improve passing and control skills for athletes aged 12-14 years.
\end{abstract}

Keywords : model of training; passing and soccer control; small side games

\section{Introduction}

In football there are various kinds of actions carried out, based on the aim of football to score goals, passing and control techniques into a football action that aims to create goal opportunities. Widdows and Buckle (2007: 23) in Santoso (2014: 43) that "football is a team game and passing is the most appropriate technique used by soccer players to connect the players". In this case passing is a tool to progress the ball forward by passing opponents or moving opponents (Danurwindo, Putera, \& Sidik, 2017: 11). A game sometimes uses onetouch passing to see the game situation, but in the implementation there will be a ball control technique that will lead to the next set of games.

In accordance with the statement, the implementation of passing will tend to appear with ball control ready for further action. So the reaction speed of the control ready to use will support the speed of a game that is coupled with the flow of passing ball. David Goldlatt and Johnny Acton stated in his book that "No matter how perfectly a pass is delivered, it will be wasted if the receiver fails to control the ball effectively" (Goldlat, D \& Acton, J, 2018: 118), this has it means that in any form the bait will be in vain if the recipient fails to control the ball effectively or controls the ball ready for further action. According to Sucipto, et al. (2000: 22), Stopping the ball is one of the basic techniques in soccer games that use it together with kicking ball techniques. 
From the above definitions, it can be concluded that the basic passing and control techniques are very important in football, both of which have a strong connection in the execution of a game, touching possession when controlling the ball greatly influences the subsequent passing performance in the run of running a series of games with the team. Good quality of mastery of this technique will produce cohesiveness and cooperation between players can occur and can be a defensive factor and in initiating attacks. Small Side Games (SSG);

The small side games exercise is a training model that is already familiar to soccer coaches. The method for training small side games has its own characteristics in the form of restrictions when playing. These restrictions are such as limiting the number of players, touching the ball, playing time and the size of the playing field. Rampinini (2007: 665) states that "intensity in small-side soccer games can be manipulated by varying the type of exercise, field dimensions, and whether or not the coach provides encouragement." So to determine the training load can be made through restrictions when carrying out training in a small field.

Specific rules for the course of the game and restrictions applied aim to develop the ability to pass and control using certain legs. Available studies show that physiological responses, requirements for tactical and technical skills can be modified during small matches by changing factors such as number of players, size of the game, rules of the game, and encouragement of the trainer (Aguiar, et al., 2012: 103).

Small side games allow players to experience the situation they face while playing an actual match, this is because in small side games almost similar to the actual game. According to quote "Small side games are widely used during football practice. These games enable players to experience situations that they encounter during actual match play. By experiencing these situations during practice, players are able to improve technical, tactical and physiological aspects of their games "(Owen et al., 2004: 50). By experiencing this situation during training, players can improve their technical, tactical and physiological aspects of the game. Compared to larger size training games, smaller sized exercises are very effective for training the touch of each player's ball.

The research results of Grant Small (2006: 32) in Scotland regarding the effect of learning small side games on young players stated that the touch of the ball was more repeated from all players with the participation of all players more active, no hiding or dominant players monopolizing the ball. Every child must participate in all aspects of the game, attack and survive. The emphasis is on developing players.

This is in accordance with the chosen constructive game approach in Indonesian football curriculum for the development of national football, "more productive games from line to line with more passing prove to be more effective in creating the opportunity to score goals" (Danurwindo, Putera, \& Sidik, 2017: 16), from which to achieve the adoption of cosmic games can be trained with small side games.

From these various opinions, it can be concluded that small side games are a method of training that uses small field sides with restrictions when playing. These restrictions are such as limiting the number of players, touching the ball, playing time and the size of the playing field. This exercise is an effective training stimulus for young football players, because it allows players to experience the situations they encounter during the actual game. By experiencing this situation during training, players can improve their technical, tactical and physiological aspects of the game.

In humans, physical, psychomotor and psychological abilities will develop according to the age level and level of physical growth. From childhood to adulthood will experience various developments including physiological, psychological, intellectual, social and mobility 
development. From the results of the study of Marcio Domingues (2013: 12) concluded that "An important aspect of growth, development, and maturation is particularly important, as a youngster's football, the performance may depend greatly on gender and biological age and state". The conclusion emphasizes the importance of understanding the coach or coach of football about important aspects of the growth, development and maturation of players, because the football performance of young people may be very dependent on gender and biological age and country.

The occurrence of several changes in the body which includes the development of rapid height, visible from the Adam's apple in the neck, enlarged volume and grow hair in several parts of the body. His interest in physical activity is increasing, imagination, curiosity and social activities are also increasing. Like group activities and games (Narbito, 2008: 4).

Another opinion states that at the age of 12-14 years more like games and matches that use official regulations and are more organized, want to be recognized and accepted as group members, loyalty to a very prominent group (Jamalong, 2014: 160). So in this age range it is appropriate to provide learning or training about the forms of games that are group or team.

Basic technical training in playing advanced football given is a continuation of the techniques that have been mastered before, so that the quality of the technique is slowly improved with several approaches taken in providing training material, in this case the trainer must be creative in presenting training material, because at this age experiencing puberty. This phase is very effective for players learning new soccer action skills (Danurwindo, Putera, \& Sidik, 2017: 65).

\section{Research Method}

This study uses a type of research and development approach. This study adopts the stages of development proposed by Borg and Gall. This development study found the final results of passing and control skill training models based on small side games for ages 12-14 years and tested their effectiveness.

This research and development included 60 subjects in conducting their research, the subject was from football school students. For data collection carried out using observation, interviews, questionnaires and tests of effectiveness. The development of the model from Borg and Gall has ten steps in the stages described in Figure 1.

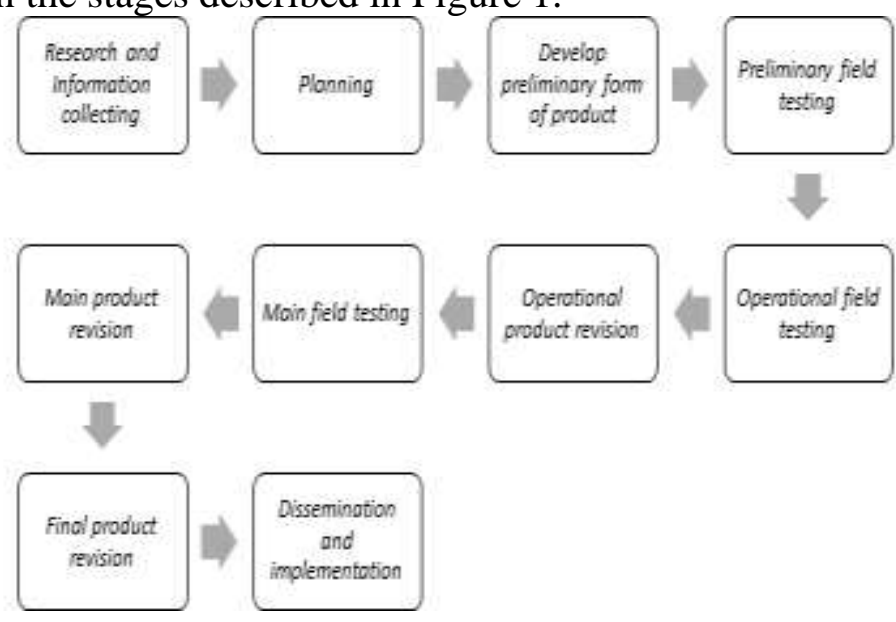

Figure 1. Steps of Research and Development from Borg and Gall 
Data analysis in this study was conducted qualitatively and quantitatively. After that, through small group trials, large group trials and effectiveness tests. The effectiveness test of this study used the Pre-test and Post-test significance test with the Loughborough Soccer Passing Test (LSPT) instrument.

In this test the assessment was taken from the time obtained by the implementation of 16 passes to the target, so the bait sequence was randomly generated by the researcher, each test consisted of 8 long feeds ( $4 \mathrm{~m}$, green and blue) and 8 short feeds $(3.5 \mathrm{~m}$, white and red).

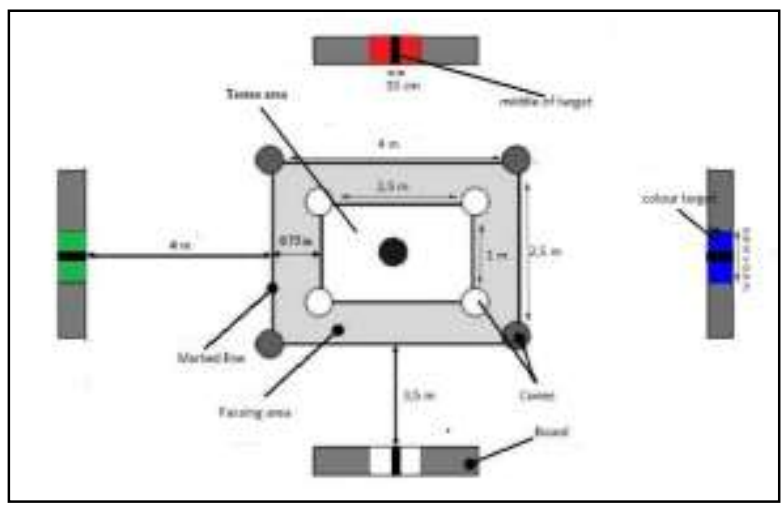

Figure 2. Loughborough Soccer Passing Test (LSPT)

Source (BenOunis et al., 2013)

\section{Discussion}

This research and development begins with an analysis of needs in the field, along with some results of the analysis of needs that have been carried out.

Tabel 1. Results of Need Analysis

\begin{tabular}{|c|c|}
\hline Method & Conclusion of Data \\
\hline Interview & $\begin{array}{l}\text { - Interviews with trainers state that there is minimal reference } \\
\text { to material for passing and control that varies } \\
\text { - It's needed a variety of passing and control training models } \\
\text { with small side-based games. }\end{array}$ \\
\hline Observation & $\begin{array}{l}\text { - Found that the exercise was only carried out by the drill } \\
\text { method } \\
\text { - The ability to master passing and control skills still looks } \\
\text { lacking }\end{array}$ \\
\hline Questionnaires & $\begin{array}{l}\text { - The results of the distribution of questionnaires obtained from } \\
\text { athletes or soccer players aged 12-14 years showed a } \\
\text { percentage of } 64.96 \% \text { (Sixty four point ninety six percent) } \\
\text { - From these results we can draw conclusions from the } \\
\text { questionnaires that variations in the model of soccer passing } \\
\text { and control skills are needed. }\end{array}$ \\
\hline
\end{tabular}

The results of this needs analysis can be stated that the model of passing and control soccer skills based on small side games is necessary for practicing the skills of passing and 
player control techniques, and with the results of the analysis of the requirements, a draft model is drawn up.

As a first step in the preparation of the product passing and control soccer skills training model based on small side games, the researchers made a structured product design of 30 variations of training model items, with the distribution of training models easy, medium and difficult. From the classification division, the model designed will be related. So model 1 is easy, 1 medium and 1 are difficult to use in a training session. The design of the training models designed is as follows:

Tabel. 2 First Draft Concept

\begin{tabular}{|c|c|c|c|}
\hline \multicolumn{3}{|c|}{ Exercise Model Item } & \multirow{4}{*}{$\begin{array}{l}\text { Information } \\
\text { - Purpose : } \\
\text { Train football passing and control skills } \\
\text { - Implementation: } \\
\text { In accordance with the instructions in each } \\
\text { model item }\end{array}$} \\
\hline $\begin{array}{l}\text { Easy } \\
\text { Model } \\
\text { Items }\end{array}$ & $\begin{array}{l}\text { Medium } \\
\text { Model Item }\end{array}$ & $\begin{array}{l}\text { Difficult } \\
\text { Model Items }\end{array}$ & \\
\hline$S S G A N 1$ & SSG AN 11 & SSG AN 21 & \\
\hline$S S G A N 2$ & GAN 12 & & \\
\hline SSG AN 3 & N 13 & & - Facilities and infrastructure: \\
\hline$S S G A N 4$ & AN 14 & 24 & 1. Footb \\
\hline SSG AN 5 & SSG AN 15 & SSG AN 25 & 2. Ball \\
\hline$S S G A N 6$ & SSG AN 16 & SSG AN 26 & 3. Cone Cones and Markers \\
\hline SSG AN 7 & SSG AN 17 & SSG AN 27 & 4. Vest \\
\hline$S S G A N 8$ & SSG AN 18 & $S S G A N 28$ & 5. Small and Medium Goals \\
\hline SSG AN 9 & SSG AN 19 & SSG AN 29 & \\
\hline SSG AN 10 & SSG AN 20 & SSG AN 30 & \\
\hline 10 Items & 10 Items & 10 Items & Total 30 Item Model Exercises \\
\hline
\end{tabular}

The table above is an initial draft concept that was made by the researcher. The concept of the initial draft was made to the maximum extent possible by basing on the results of needs analysis and theoretical studies. So that with these results the draft concept of the initial model contained 30 (thirty) model items.

The concept of the initial draft model in the table above is still not included in the model feasibility test phase. The stage of the feasibility test involves several experts who are competent in their field according to the material of this study. The feasibility test of this model involves three experts in the field of football, namely 2 football coaches and 1 sports coach.

The purpose of the model feasibility test is to obtain the results of validation or feasibility of the model that has been designed. The researcher conducts a model feasibility test involving experts or experts who then draw conclusions from the draft model that has been made that from the overall initial model, 24 (twenty four) items of the model are deemed feasible to be implemented and 6 (six) model items are declared not feasible to implement. So that the total items of the initial model as a whole number 30 (thirty) training model items into 24 (twenty four) training models that can be implemented. A total of 6 (six) model items (SSG AN 1, 11, 21 and SSG AN 4.14,24) were declared inappropriate because some of the models when run tend to come out from the core material model, namely passing and control and there are too difficult model items to run.

Expert tests conducted by 3 experts have several suggestions for perfecting the validated training model:

1. The training model items must be arranged systematically and according to the stages of the exercise, so the easy, medium and difficult model items that are related are 
given different names or signs so that it will be easier to choose the model items to be applied.

2. Some models need to be modified according to the difficulty, so that they can conform to the concepts of easy, medium and difficult.

3. The instruction points for passing and control training materials must be strong, and some variations in the field must focus on the training points.

4. At the time of implementation, always create a comfortable and pleasant atmosphere, insert instructions that make athletes enjoy training.

5. The name of the training model item is adjusted according to the form of the model item, so the perception before implementation will be a clear name and in accordance with the implementation.

After revisions and products are repaired, the product is feasible to use in the initial field trials or small group trials. Application of the model in the field at the time of small group trials by observing the feasibility of the model made. The results of the small group trials are shown in the table below.

Table 3. Small Group Trial Results

\begin{tabular}{|c|c|c|c|}
\hline \multicolumn{3}{|c|}{$\begin{array}{l}\text { Small Group Trial } \\
\text { Exercise Model Items }\end{array}$} & \multirow{2}{*}{ INFORMATION } \\
\hline $\begin{array}{l}\text { Easy } \\
\text { Model Items }\end{array}$ & $\begin{array}{l}\text { Medium } \\
\text { Model Item }\end{array}$ & $\begin{array}{l}\text { Difficult } \\
\text { Model Items }\end{array}$ & \\
\hline$S S G A N 2$ & SSG AN 12 & SSG AN 22 & Can Be Implemented \\
\hline$S S G A N 3$ & SSG AN 13 & $S S G A N 23$ & Can Be Implemented \\
\hline SSG AN 5 & SSG AN 15 & SSG AN 25 & Can Be Implemented \\
\hline SSG AN 6 & SSG AN 16 & SSG AN 26 & Can Be Implemented \\
\hline$S S G A N 7$ & SSG AN 17 & SSG AN 27 & Can Be Implemented \\
\hline$S S G A N 8$ & SSG AN 18 & SSG AN 28 & Can Be Implemented \\
\hline SSG AN 9 & SSG AN 19 & SSG AN 29 & Can Be Implemented \\
\hline SSG AN 10 & SSG AN 20 & SSG AN 30 & Can Be Implemented \\
\hline 8 Items & 8 Items & 8 Items & Can Be Implemented \\
\hline
\end{tabular}

From the table above, it can be seen the results of the small group trial recapitulation of all models of football passing and control training based on small side games that can be implemented for athletes aged 12-14 years.

Based on the results of small group trials that have been carried out and obtained the results of the recapitulation, the model of passing and control based on small side games conducted can be summarized as follows.

1. Training model items can be applied to athletes aged 12-14 years, but must always be emphasized to athletes to focus on applying passing and control.

2. The model items that are made are good, but the size of the field grid needs to be considered to be adjusted.

3. The model items that are divided into easy, medium and difficult can be carried out sequentially according to the concept that has been made. 
4. When the implementation of the implementation instructions must be clear, so that the implementation minimizes the implementation errors.

5. Overall items of the small side games football passing and control training model can be applied to 12-14 year old athletes, to provide a variety of exercises with passing and control skills and provide training experience that approaches the real situation during the match.

After revision or improvement from the results of small group trials, the next step is the main field trials or large group trials. In large group trials involving more subjects than small group trials. The analysis carried out in this large group trial is the same as the analysis technique in small group trials. The following are the results of data analysis on the implementation of large group trials.

Table 4. Large Group Trial Results

\begin{tabular}{|c|c|c|c|}
\hline \multicolumn{3}{|c|}{$\begin{array}{l}\text { Large Group Trial } \\
\text { Exercise Model Items }\end{array}$} & \multirow{2}{*}{ INFORMATION } \\
\hline $\begin{array}{l}\text { Easy } \\
\text { Model Items }\end{array}$ & $\begin{array}{l}\text { Medium } \\
\text { Model Item }\end{array}$ & $\begin{array}{l}\text { Difficult } \\
\text { Model Items }\end{array}$ & \\
\hline$S S G A N 2$ & SSG AN 12 & SSG AN 22 & Can Be Implemented \\
\hline SSG AN 3 & SSG AN 13 & $S S G A N 23$ & Can Be Implemented \\
\hline$S S G A N 5$ & SSG AN 15 & SSG AN 25 & Can Be Implemented \\
\hline SSG AN 6 & SSG AN 16 & $S S G A N 26$ & Can Be Implemented \\
\hline SSG AN 7 & SSG AN 17 & SSG AN 27 & Can Be Implemented \\
\hline$S S G A N 8$ & SSG AN 18 & SSG AN 28 & Can Be Implemented \\
\hline SSG AN 9 & SSG AN 19 & $S S G A N 29$ & Can Be Implemented \\
\hline SSG AN 10 & SSG AN 20 & SSG AN 30 & Can Be Implemented \\
\hline 8Items & 8 Items & 8 Items & Can Be Implemented \\
\hline
\end{tabular}

From the table above, it was found that in the large group trials the application of items for the passing and control training model based on small side games for 12-14 year olds could be used. In other words the exercise model that has been created has been achieved in accordance with the initial objectives in making the training model.

During the trial of this large group there were no significant obstacles. As for the things that need to be considered from the results of the application of the training model that is the instruction to the athlete when the implementation must always be clear so that the athlete understands the rules for each model.

After conducting a large group trial or main field trial, the model of passing and control training based on small side games for ages 12-14 years is the final product. This final product is the result of a large group trial, if there is no revision the model made is final and has met the feasibility to be used or implemented.

The next step is to carry out the effectiveness test, the purpose of this test to see how effective the training model has been produced. This test is conducted by involving football athletes aged 12-14 years as many as 30 (thirty) athletes. 
The data generated on the effectiveness test bases on quantitative data. Product effectiveness tests were made using a pretest-posttest control group design, ie two groups randomly selected, were previously given a pre-test to determine the initial state of the experimental group and the control group, after getting the results, the experimental group was treated with passing and control skills football based on small side games, while the control group was not treated. After being given treatment from an exercise in one group (experimental group), the next step was carried out by the researcher by doing a post-test to both groups, namely the experimental group and the control group.

The data generated on the effectiveness test bases on quantitative data. Product effectiveness tests were made using a pretest-posttest control group design, ie two groups randomly selected, were previously given a pre-test to determine the initial state of the experimental group and the control group, after getting the results, the experimental group was treated with passing and control skills football based on small side games, while the control group was not treated. After being given treatment from an exercise in one group (experimental group), the next step was carried out by the researcher by doing a post-test to both groups, namely the experimental group and the control group.

If there is a significant difference between the experimental group and the control group, the treatment given in this case the passing and control skills of football based on small side games has a significant effect. The following are the results of processing the assessment data of 30 athletes in the experimental group using SPSS 16.0.

Tabel 5. Experimental Data Normality

\begin{tabular}{|c|c|c|c|c|}
\hline \multicolumn{5}{|l|}{ Tests of Normality } \\
\hline & \multicolumn{2}{|c|}{ Kolmogorov-Smirnov } & \multicolumn{2}{|c|}{ Shapiro-Wilk } \\
\hline & Statistic df & Sig. & Statistic & df Sig. \\
\hline PRE_EKSPERIMEN & .096 & $.200^{*}$ & .971 & 30.575 \\
\hline POST_EKSPERIMEN & .137 & 156 & .953 & 30.199 \\
\hline
\end{tabular}

Source: Results of data processing

Based on the above table which has been calculated using SPSS from the Shapiro-Wilk normality test obtained normality data in the pre-test 0.575 and in the post-test 0.199 then both data are greater than alpha 0.05 . thus both data are normally distributed.

Table 6. Results of paired samples statistics of the experimental group pre-test and post-test

$$
\text { Paired Samples Statistics }
$$

\begin{tabular}{lllll}
\hline \multicolumn{2}{c}{ EKSPERIMEN } & Mean N & Std. Deviation & Std. Error Mean \\
\hline Pair 1 & PRE_TEST & 53.8830 & 2.718 & .496 \\
\cline { 2 - 5 } & POST_TEST & 47.6130 & 1.838 & .336 \\
\hline
\end{tabular}

Source: Results of data processing 
The results of the average pre-test scores that were carried out before being given the treatment of the passing and control skills training model based on small side games were 53.88 and after being treated the average score was 47.61. In the assessment taken, it is in the form of a measure of time. So the post-test value will tend to decrease in value, smaller than the pretest. This can be interpreted, that the smaller the time gained, there is an increase after the passing and control skills group.

Table 7. Results of paired samples correlation pre-test and post-test experimental group

\section{Paired Samples Correlations}

\begin{tabular}{clll}
\hline & $\mathrm{N}$ & Correlation & Sig. \\
\hline $\begin{array}{c}\text { Pair 1 PRE_EKSPERIMEN \& } \\
\text { POST_EKSPERIMEN }\end{array}$ & 30 & .761 & .000
\end{tabular}

Source: Results of data processing

Based on the values in the table above, the results of the correlation coefficients before and after being treated were obtained, namely $0.761 \mathrm{p}$-value $0.00<0.05$ so the conclusion was that there was a significant relationship.

Table 8. Results of paired samples in the experimental group pre-test and post-test

\section{Paired Samples Test}

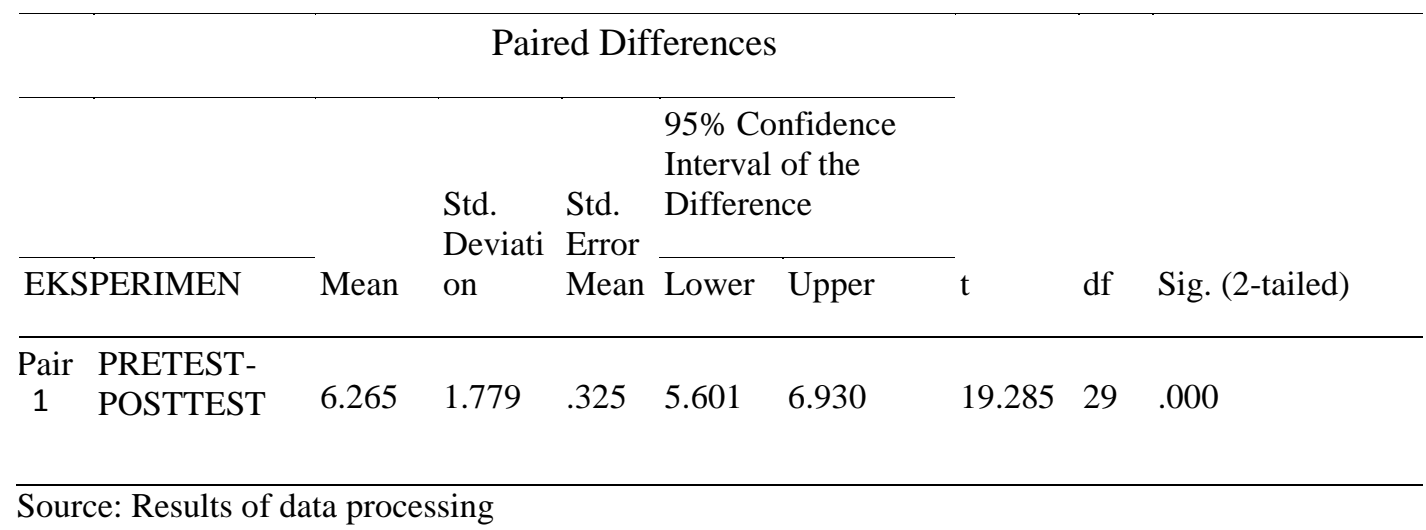

In a significant test the difference with SPSS 16 shows that the mean $=6.265$ shows the difference from the results of the pre-test and post-test results, $\mathrm{df}=29$, the results of tcount $=$ $19,285>$ t table 2,042 (from $n=30$ ) and $p$-value $=0.00<0.05$ means that there is a significant difference between before and after being given the treatment of the passing and control skills training model based on small side games for ages 12-14 years.

Based on these results it can be concluded that the passing and control skills training model based on small side games for 12-14 year olds is effective and can improve the passing and control skills of athletes aged 12-14 years. The exercise model applied to the treatment for the experimental group has significant effectiveness.

Furthermore the results data obtained from the assessment of 30 athletes in the control group are shown in the results of data processing using SPSS 16.0 below. 
Table 9. Control Group Data Normality

\begin{tabular}{|c|c|c|c|c|c|c|}
\hline \multicolumn{7}{|c|}{ Tests of Normality } \\
\hline \multirow[b]{2}{*}{ KONTROL } & \multicolumn{3}{|c|}{ Kolmogorov-Smirnov ${ }^{\mathrm{a}}$} & \multicolumn{2}{|c|}{ Shapiro-Wilk } & \multirow[b]{2}{*}{ Sig. } \\
\hline & Statistic & df & Sig. & Statistic & df & \\
\hline PRE_TEST & .120 & 30 & $.200^{*}$ & .937 & 30 & .077 \\
\hline POST_TEST & .131 & 30 & $.200^{*}$ & .938 & 30 & .081 \\
\hline
\end{tabular}

Source: Results of data processing

Based on the above table which has been calculated using SPSS from the Shapiro-Wilk normality test obtained normality data in the pre-test 0.077 and in the post-test 0.081 , the two data are greater than alpha 0.05 . thus both data come from populations that are normally distributed.

Tabel 10. Results of paired samples statistics of the control group pre-test and post-test

\begin{tabular}{|c|c|c|c|c|}
\hline \multicolumn{5}{|c|}{ Paired Samples Statistics } \\
\hline CONTROL & Mean & $\mathrm{N}$ & Std. D & Std. Error Mean \\
\hline Pair PRE_TEST & 52.99 & 30 & 2.545 & .465 \\
\hline POST_TEST & 49.80 & 30 & 2.516 & .459 \\
\hline
\end{tabular}

Source: Results of data processing

The results of the average pre-test and post-test scores carried out in the control group were 52.99 pre-test and received a post-test average value of 49.80. In the assessment taken, it is in the form of a measure of time.

Tabel 11. Results of paired samples correlation pre-test and post-test control group

\begin{tabular}{lllll}
\hline Paired Samples Correlations & & & \\
\hline & $\mathrm{N}$ & Correlation & Sig. \\
\hline $\begin{array}{l}\text { Pair } \\
1\end{array}$ & PRE_TEST \& POST_TEST & 30 & .887 & .000 \\
\hline
\end{tabular}

Source: Results of data processing

Based on the values in the table above, the correlation coefficients of the results before and after training were obtained, namely $0.887 \mathrm{p}$-value $0.00<0.05$ so the conclusion was that there was a significant relationship. 
Tabel 12. The results of the paired samples were the pre-test and post-test groups in the control group

Paired Samples Test

\begin{tabular}{|c|c|c|c|c|c|c|c|}
\hline & \multicolumn{5}{|c|}{ Paired Differences } & \multirow{3}{*}{ df } & \multirow[b]{2}{*}{$\begin{array}{l}\text { Sig. } \\
\text { (2-tailed) }\end{array}$} \\
\hline & Mean & $\begin{array}{l}\text { Std. } \\
\text { Deviation }\end{array}$ & $\begin{array}{l}\text { Std.Error } \\
\text { Mean }\end{array}$ & $\begin{array}{l}95 \% \text { Confidence } \\
\text { of the Difference }\end{array}$ & Interval & & \\
\hline CONTROL & & & & Lower & Upper & & \\
\hline $\begin{array}{l}\text { Pair } 1 \text { PRE_TEST- } \\
\text { POST_TEST }\end{array}$ & 3.186 & 1.206 & .220 & 2.736 & 3.637 & 14.47529 & .000 \\
\hline
\end{tabular}

Based on the table above and the SPSS results show the results of the pre-test and posttest in the control group, in the significant test the difference found mean $=3.186$ shows the exclusion of the results of the pre-test and post-test results, $\mathrm{df}=29$, $\mathrm{t}$-count results $=14,475>$ t-table 2,042 (from $n=30$ ) and $p$-value $=0.00<0.05$ which means there are differences.

Next to see the effect of treatment based on its significance is to use the two mean independent mean difference test. The analysis of the independent sample t-test on the experimental group post-test and the post-test control group aimed to determine whether there were significant differences in the post-test scores in the two groups.

Table 13. Group Statistics post-test control group and experimental group post-test

Group Statistics

\begin{tabular}{llllll}
\hline KELOMPOK & $\mathrm{N}$ & Mean & Std. Deviation & Std. Error Mean \\
\hline POST_ & KONTROL & 30 & 49.80 & 2.516 & .459 \\
\cline { 2 - 6 } TEST & EKSPERIMEN & 30 & 47.61 & 1.838 & .336 \\
\hline
\end{tabular}

Source: Results of data processing

Table 14. Results of the analysis of independent-sample t-test on the experimental group post-test and control group post-test

\section{Independent Samples Test}

Levene's Test

for Equality

of Variances t-test for Equality of Means

95\% Confidence

Interval of the

Sig.

Difference

\begin{tabular}{|c|c|c|c|c|c|c|c|c|c|}
\hline \multirow[b]{2}{*}{ POST_TEST } & \multirow[b]{2}{*}{$\mathrm{F}$} & \multirow[b]{2}{*}{ Sig. } & \multirow[b]{2}{*}{$\mathrm{t}$} & \multirow[b]{2}{*}{$\mathrm{df}$} & \multirow{2}{*}{ (2-tailed) } & \multirow{2}{*}{$\begin{array}{l}\text { Mean } \\
\text { Difference }\end{array}$} & \multirow{2}{*}{$\begin{array}{l}\text { Std. Error } \\
\text { Difference }\end{array}$} & \\
\hline & & & & & & & & Lower & Upper \\
\hline $\begin{array}{l}\text { Equal variances } \\
\text { assumed }\end{array}$ & 5.324 & .025 & 3.845 & 58 & .000 & 2.188 & .569 & 1.049 & 3.327 \\
\hline $\begin{array}{l}\text { Equal variances } \\
\text { not assumed }\end{array}$ & & & 3.845 & 53.091 & .000 & 2.188 & .569 & 1.046 & 3.329 \\
\hline
\end{tabular}


Based on the results of the difference test it can be concluded that the results obtained are based on the SPSS 16 statistical count in the experimental group with an average of 47.61 and the control group with an average of 49.80, the results derived from the test scores in the form of the final time velocity, so the time is smaller the better it gets. Fill in the results of the experimental group and the control group or mean difference $=2.188$, t-count $=3.845, \mathrm{df}=58$, with $\mathrm{p}$-value $=0.000<0.05$, so it can be concluded that there are significant differences between the experimental group and the control group.

These results indicate that the treatment given to the experimental group, namely the passing and control soccer skills training model based on small side games for 12-14 year olds has higher effectiveness and can improve passing and control skills for athletes aged 12-14 years.

\section{Conclusion}

The conclusion of this study is that it begins with the findings in the field relying on needs analysis, finding that the mastery skills of passing and control skills are still lacking in athletes aged 12-14 years. So that with some studies determine by using the small side games method in practicing passing and control skills. So that it can be stated that the product in the form of a passing and control skill training model using small side games is really in accordance with the needs in the field. In the end it has produced an answer with the existence of a product in the form of a passing and control soccer skills training model based on small side games for 12-14 years old with 24 training model items, the resulting exercise model has higher effectiveness and can improve passing skills and control in athletes aged 12-14 years.

\section{References}

Aguiar, M., Botelho, G., Lago, C., MaçAs, V., \& Sampaio, J. (2012). A review on the effects of soccer small-sided games. Journal of Human Kinetics, 33(1),103-113. https://doi.org/10.2478/v10078-012-0049-X

BenOunis, O., BenAbderrahman, A., Chamari, K., Ajmol, A., BenBrahim, M., Hammouda, A., ... Zouhal, H. (2013). Association of short-passing ability with athletic performances in youth soccer players. Asian Journal of Sports Medicine, 4(1), 41-48. https://doi.org/10.5812/asjsm.34529

Danurwindo, Putera, G., \& Sidik, B. (2017). Kurikulum Pembinaan Sepakbola Indonesia. Jakarta: High Performance Unit PSSI.

Domingues, M. (2013). Growth and Functional Development in 6 to 10 Years Old Soccer Players: Constraints and Possibilities. Annals of Applied Sport Science, 1(4), 5-15.

Gall, M. D., Gall, J. P., \& Borg, W. R. (2003). Educational Research (Seventh edition). Educational Research: An Introduction. Retrieved from.

Harsono, (2015). Kepelatihan Olahraga. Bandung: Remaja Rosdakarya.

Jamalong, A. (2014). Peningkatan prestasi olahraga nasional secara dini melalui pusat pembinaan dan latihan pelajar (PPLP) dan pusat pembinaan dan latihan mahasiswa (PPLM). Jurnal Pendidikan Olahraga, 3(2), 156-168.

Owen, Adam; Twist, Craig; Ford, P. (2004). Small-Sided Games: the Physiological and Technical Effect of Altering Pitch Size and Player Numbers. Insight, 7(2), 50-53.

Rampinini, E., Impellizzeri, F. M., Castagna, C., Abt, G., Chamari, K., Sassi, A., \& Marcora, S. M. (2007). Factors influencing physiological responses to small-sided soccer games. Journal of Sports Sciences, 25(6), 659-666. https://doi.org/10.1080/02640410600811858 Santoso, N. (2014). Tingkat Keterampilan Passing-Stoping Dalam Permainan Sepakbola Pada 
www.bircu-journal.com/index.php/birle emails: birle.journal@gmail.com birle.journal.qa@gmail.com

Mahasiswa Pjkr B Angkatan 2013. Jurnal Pendidikan Jasmani Indonesia, Volume 10,(November), 40-48.

Scheunemann, Timo. (2012). Kurikulum Sepak Bola Indonesia untuk Usia Dini, Usia Muda dan Senior. Jakarta: PSSI.

Sucipto dkk. (2000). Sepak Bola. Jakarta: Depdikbud: Dirjendikti.

Tangkudung, James \& Puspitorini, W. (2006) Kepelatihan Olahraga, "Pembinaan Prestasi Olahraga". Jakarta: Cerdas Jaya 